\title{
O CUMPRIMENTO DOS LIMITES FISCAIS RELATIVOS À DÍVIDA CONSOLIDADA LÍQUIDA NO ESTADO DE SANTA CATARINA ENTRE OS ANOS DE 2000 E 2013
}

\author{
THE FISCAL LIMITS COMPLIANCE RELATED TO THE NET CONSOLIDATED DEBT IN \\ SANTA CATARINA STATE BETWEEN THE YEARS 2000 AND 2013
}

\author{
Gustavo Gaspary da Silva \\ gustavaogaspary@gmail.com \\ Universidade Federal de Santa Catarina
}

\author{
Orion Augusto Platt Neto \\ orion.platt@ufsc.br \\ Universidade Federal de Santa Catarina
}

Resumo: A Constituição Federal de 1988 definiu ao Senado Federal competência privativa para fixar os limites globais para o montante da Dívida Consolidada de todos os entes públicos. Diante disso, no ano de 2001, mediante proposta do Presidente da República, foi editada a Resolução n. ${ }^{\circ} 40$ para estabelecer tais limites. Neste contexto, o presente artigo tem como objetivo identificar se no Estado de Santa Catarina houve cumprimento dos limites fiscais relativos à Dívida Consolidada Líquida (DCL) entre os anos de 2000 e 2013. Quanto aos objetivos, esta pesquisa é classificada como descritiva; com abordagem qualitativa e quantitativa. Quanto aos procedimentos metodológicos, classifica-se como pesquisa bibliográfica e documental. Como fontes de dados, foram utilizados os demonstrativos contábeis sobre a DCL presentes nos Relatórios de Gestão Fiscal (RGF) do Estado de Santa Catarina referentes aos anos de 2000 a 2013, além das normas vigentes sobre a dívida pública. Pôde-se verificar que a relação da DCL com a Receita Corrente Líquida (RCL) foi reduzida de $183 \%$ para $48 \%$ entre os anos de 2000 e 2013. Tal redução deu-se em função da elevação da RCL e da diminuição da DCL ao longo da série. Em valores atualizados pela inflação, a DCL passou de $\mathrm{R} \$ 13,6$ bilhões para $\mathrm{R} \$ 7,6$ bilhões entre os anos de 2000 e 2013. A RCL, por sua vez, teve comportamento inverso à $\mathrm{DCL}$, iniciando a série com $\mathrm{R} \$ 7,6$ bilhões no ano de 2000 e encerrando 2013 com R\$ 16,4 bilhões. Por meio de análise dos dados obtidos nos demonstrativos contábeis, conclui-se que em todos os anos analisados o Estado demonstrou cumprimento do limite fiscal de $200 \%$ da RCL, conforme estabelecido na Resolução do Senado Federal.

Palavras-chave: Dívida Consolidada. Dívida Pública. Limites Fiscais. Estado de Santa Catarina.

ABSTRACT: The Federal Constitution of 1988 defined the Federal Senate exclusive authority to set global limits on the amount of Consolidated Debt of all public entities. Thus, in 2001, upon proposal of the President, was issued Resolution $n^{o} .40$ to establish such limits. In this context, this article aims to identify whether the Santa Catarina State there was compliance with the fiscal limits on Net Consolidated Debt (DCL) between the years 2000 and 2013. As to the objectives, this research is classified as descriptive; with qualitative and quantitative approach. In the methodological procedures, ranks as bibliographic and documentary research. As data sources, the financial statements on the DCL present in Fiscal Management Reports (RGF) of the Santa Catarina State for the years 2000 to 2013, in addition to the current rules on public debt were used. It was verified that the ratio of DCL with the Net Current Revenue (RCL) was reduced from 183\% to $48 \%$ between 2000 and 2013. This reduction took place due to the increase of RCL and a decrease in the DCL throughout the series. In figures adjusted for inflation, the DCL from $R \$ 13.6$ billion to $R \$ 7.6$ billion between 2000 and 2013. The RCL, in turn, had an opposite behavior to the DCL, starting the series with $R \$ 7.6$ billion in 2000 and ending in 2013 with $R \$ 16.4$ billion. Through analysis of the data obtained in the financial statements, it appears that in all analyzed years, the State 
has demonstrated compliance with the fiscal limit of $200 \%$ of RCL, as set out in Resolution of the Senate.

Keywords: Consolidated Debt. Public Debt. Fiscal Limits. Santa Catarina State.

Artigo recebido em: 17/03/2015; Aceito em: 06/10/2015

\section{INTRODUÇÃO}

Em algumas situações, a arrecadação dos entes públicos é insuficiente para cobrir os gastos, ou a execução orçamentária não ocorre de acordo com o que foi previsto. Nesse contexto, surge a necessidade de contrair dívidas, contornando assim um possível déficit orçamentário, para complementar a receita (equilibrando o orçamento), ou suprir um déficit financeiro, para cobertura imediata por falta de disponibilidade em caixa.

Contudo, o uso de recursos de terceiros para suprir o erário é disciplinado e fiscalizado, para que não seja aplicado de forma irresponsável. Para tanto, foi estabelecido na Constituição Federal que é de competência privativa do Senado Federal "fixar, por proposta do Presidente da República, limites globais para o montante da dívida consolidada da União, dos Estados, do Distrito Federal e dos Municípios" (BRASIL, 1988, art. 52, VI).

Com o surgimento da Lei Complementar n. ${ }^{\circ}$ 101/2000 (Lei de Responsabilidade Fiscal - LRF), a proposta do Presidente da República para os limites ficais deveria ser submetida ao Senado Federal dentro de noventa dias, após a publicação da LRF (BRASIL, 2000, art. 30, I). Dessa forma, percebe-se a busca por uma gestão fiscal responsável, visando cumprir limitações previstas na Constituição Federal.

A Resolução n. ${ }^{\circ}$ 40/2001 do Senado Federal estabelece que o limite global da Dívida Consolidada Líquida (DCL) dos estados não pode exceder a duas vezes o valor da Receita Corrente Líquida (RCL) até o décimo quinto exercício financeiro, após a publicação desta resolução (SENADO FEDERAL, 2001, arts. $3^{\circ}$ e $4^{\circ}$ ). Diante do limite existente, os estados possuem a obrigação de evidenciar em demonstrativo contábil próprio a composição da DCL e o cumprimento, ou não, do limite do Senado Federal. Tal demonstrativo deve ser público, embora nem sempre apresente fácil disponibilidade ou entendimento da população.

O problema investigado na pesquisa que deu base para este artigo é envolvido pela seguinte pergunta: houve cumprimento dos limites fiscais relacionados à Dívida Consolidada Líquida (DCL) no Estado de Santa Catarina entre os anos de 2000 e 2013 ?

Esta pesquisa apresenta como objetivo identificar se no Estado de Santa Catarina houve cumprimento dos limites fiscais relativos à DCL entre os anos de 2000 e 2013. Diante da exigência normativa e das fontes de dados existentes, este artigo identifica e apresenta os dados da DCL aplicáveis na apuração do limite fiscal, monetariamente e percentualmente. Além disso, evidencia a evolução das variáveis ao longo dos anos dessa série histórica, ajustados por um índice de preços, com vistas a diminuir as distorções da inflação.

O artigo está delimitado a cumprir o objetivo expresso, mediante a realização dos procedimentos metodológicos e a aplicação dos instrumentos descritos no Capítulo 3 . $\mathrm{O}$ artigo não tem o propósito de apresentar justificativas econômicas e políticas das esferas federal e estadual que, de alguma forma, poderiam ter influenciado na origem e na evolução da DCL. Não são feitas críticas às normas aplicáveis aos limites, nem são questionados os critérios contábeis seguidos pelo ente. Adicionalmente, não são analisados os fatos históricos associados aos dados observados e não há a intensão de explicar os resultados por meio de relações de causa e efeito. Ações nesse sentido são sugeridas no capítulo de conclusões, para pesquisas futuras.

R. Cont. Ufba, Salvador-Ba, v. 9, n. 3, p. 64 - 82, set-dez 2015 
O presente trabalho justifica-se por sua relevância potencial nos contextos governamental e social. No contexto governamental, o trabalho justifica-se porque analisa a DCL de um ente público em um intervalo de quatorze anos, com horizonte de evolução de dados corrigidos para favorecer a comparação, e série de limites fiscais com valores originais para evidenciação do cumprimento normativo em cada ano. Deste modo, essa pesquisa possibilita ao gestor público uma visão histórica sobre a situação da DCL no Estado de Santa Catarina, sem a pretensão de avaliar a gestão pública em todas as suas dimensões (além do fiscal) no período.

No contexto social, este artigo justifica-se porque procura apresentar à comunidade uma análise dos relatórios divulgados pelo Estado de Santa Catarina. São apresentados gráficos e tabelas para auxiliar na leitura dos demonstrativos contábeis, por vezes de difícil entendimento por apresentarem estrutura e linguagem técnicas não habituais para leigos. Dessa forma, o trabalho evidencia se os governantes do Estado de Santa Catarina cumpriram os limites sobre a DCL, previstos na LRF e fixados pelo Senado Federal.

\section{FUNDAMENTAÇÃO TEÓRICA}

\subsection{Dívida Pública}

Serão apresentados nesta seção alguns conceitos e definições sobre a dívida pública, porém sem a intenção de esgotar o assunto. Foram priorizados os termos fundamentais para abordagem do objetivo proposto para o artigo.

Entre diferentes conceitos de dívida, escolheu-se o de Sanches (2013), visto que aborda o tema de forma genérica e em consonância com o assunto tratado neste artigo. Para o referido autor (2013, p. 130), dívida é o "compromisso financeiro assumido por uma pessoa física ou jurídica - de direito público ou privado - perante outra pessoa física ou jurídica". O surgimento de uma dívida é procedimento comum em face de algum déficit, seja ele para atender a necessidade de caixa imediata, investimentos de longo prazo, ou ainda compromissos pecuniários de curto prazo e resíduos passivos, como restos a pagar (KOHAMA, 2010).

Dívida pública é aquela contraída pelas entidades do setor público das três esferas de governo, para atender três finalidades: (i) suprir déficits orçamentários; (ii) suprir déficits financeiros; e (iii) registrar depósitos e resíduos passivos. A primeira ocorre para equilibrar o orçamento; a segunda acontece quando há insuficiências de caixa ao longo do exercício financeiro; e a terceira finalidade ocorre quando o Estado atua como depositário de valores de terceiros.

A dívida pública pode ser classificada como interna e externa. Tanto para Kohama (2010) quanto para o Manual de Demonstrativos Fiscais (MDF) (STN, 2014b), dívida interna é o resultado de empréstimos contraídos dentro do país, e externa dos contraídos com credores cuja sede é no exterior. Tal critério é o proposto pelo Fundo Monetário Internacional (FMI) para divulgação das estatísticas de dívida dos países (SILVA; CARVALHO; MEDEIROS, 2009). Contudo, existe também outro critério responsável por classificar a dívida entre interna ou externa: a moeda (SILVA; CARVALHO; MEDEIROS, 2009).

Outra classificação da dívida pública é em Dívida Consolidada ou Fundada e Dívida Flutuante. Suas definições são conhecidas em diferentes instrumentos legais, tais como a Lei n. ${ }^{\circ}$ 4.320/1964, a Lei Complementar n. ${ }^{\circ}$ 101/2000 (Lei de Responsabilidade Fiscal - LRF), a Resolução n. ${ }^{\circ}$ 40/2001 do Senado Federal, o Decreto n. ${ }^{\circ}$ 93.872/1986, e o MDF.

No entanto, visto que este artigo trata dos limites fiscais de competência privativa do Senado Federal, utilizou-se da Resolução n. ${ }^{\circ}$ 40/2001 da referida instituição para definir Dívida Consolidada (DC) como (SENADO FEDERAL, 2001, art. $1^{\circ}$, III): 
III - dívida pública consolidada: montante total, apurado sem duplicidade, das obrigações financeiras, inclusive as decorrentes de emissão de títulos, do Estado, do Distrito Federal ou do Município, assumidas em virtude de leis, contratos, convênios ou tratados e da realização de operações de crédito para amortização em prazo superior a 12 (doze) meses, dos precatórios judiciais emitidos a partir de 5 de maio de 2000 e não pagos durante a execução do orçamento em que houverem sido incluídos, e das operações de crédito, que, embora de prazo inferior a 12 (doze) meses, tenham constado como receitas no orçamento;

Para a definição de Dívida Flutuante, entendeu-se que se encontra melhor explicitada no Decreto n. ${ }^{\circ}$ 93.872/1986 (BRASIL, 1986, art. 115, § $1^{\circ}$ ):

$\S 1^{\circ}$ A dívida flutuante compreende os compromissos exigíveis, cujo pagamento independe de autorização orçamentária, assim entendidos:
a) os restos a pagar, excluídos os serviços da dívida;
b) os serviços da dívida;
c) os depósitos, inclusive consignações em folha;
d) as operações de crédito por antecipação de receita;
e) o papel-moeda ou moeda fiduciária.

Diante do exposto, percebeu-se que as operações da DC estão atreladas ao orçamento, ou seja, necessitam de autorização orçamentária para sua execução. Contudo, o mesmo não ocorre com a Dívida Flutuante, cujo pagamento independe de autorização orçamentária. Essa última é contraída para atender insuficiências de caixa, ou quando o Estado atua na administração de bens e valores de terceiros (KOHAMA, 2010).

Atividades de investimentos, tais como obras de infraestrutura, muitas vezes só são possíveis de serem realizadas por meio de financiamentos. Com vistas a atender as necessidades sociais é que o Estado recorre aos empréstimos, mas sua gestão necessita ser racional, visto que além de atender as necessidades públicas, suas operações e seu montante devem atender os limites estabelecidos em normas.

Os limites para dívida são referentes à Dívida Consolidada Líquida (DCL), que é a "dívida pública consolidada, deduzidas as disponibilidades de caixa, as aplicações financeiras e os demais haveres financeiros" (SENADO FEDERAL, 2000, art. 1º, V).

\subsection{Limites Fiscais e Demonstrativos Sobre a Dívida Pública}

Para que os entes públicos possam contrair dívidas de forma responsável, a Constituição Federal definiu como competência privativa do Senado Federal, entre outros aspectos (BRASIL, 1988, art. 52, VI):

VI - fixar, por proposta do Presidente da República, limites globais para o montante da dívida consolidada da União, dos Estados, do Distrito Federal e dos Municípios;

Embora seja competência privativa do Senado Federal, a proposta dos limites globais é realizada pelo Presidente da República para as três esferas de governo. Dessa forma, em cumprimento à LRF (BRASIL, 2000, art. 30), após a proposta do Presidente da República, o Senado Federal fixou os limites globais para a DCL por meio da Resolução n. ${ }^{\circ}$ 40/2001.

Para a verificação do cumprimento do limite fiscal da DCL, a base de referência é a Receita Corrente Líquida (RCL), que é o (BRASIL, 2000, art. $2^{\circ}$, IV)

[...] somatório das receitas tributárias, de contribuições, patrimoniais, industriais, agropecuárias, de serviços, transferências correntes e outras receitas também correntes, deduzidos: [...]

b) nos Estados, as parcelas entregues aos Municípios por determinação constitucional;

R. Cont. Ufba, Salvador-Ba, v. 9, n. 3, p. 64 - 82, set-dez 2015 
c) na União, nos Estados e nos Municípios, a contribuição dos servidores para o custeio do seu sistema de previdência e assistência social e as receitas provenientes da compensação financeira citada no $\S 9^{\circ}$ do art. 201 da Constituição.

Vale ressaltar que a RCL é a base de referência para outros limites além do relativo à DCL, tais como operações de crédito interna e externas, saldo devedor das operações de antecipação da receita orçamentária, montante das garantias prestadas, para despesa com pessoal, e comprometimento anual com amortização, encargos e juros.

O limite fixado para a DCL ficou estabelecido da seguinte forma (SENADO FEDERAL, 2001, art. $3^{\circ}$, I e II):

Art. $3^{\circ}$ A dívida consolidada líquida dos Estados, do Distrito Federal e dos Municípios, ao final do décimo quinto exercício financeiro contado a partir do encerramento do ano de publicação desta Resolução, não poderá exceder, respectivamente, a:

I - no caso dos Estados e do Distrito Federal: 2 (duas) vezes a receita corrente líquida, definida na forma do art. 2; e

II - no caso dos Municípios: a 1,2 (um inteiro e dois décimos) vezes a receita corrente líquida, definida na forma do art. 2.

A proposta de limite, que serviu de base para fixação pelo Senado, precisou apresentar um rol de critérios que justificassem a escolha dos valores de parâmetros para os limites da dívida. Todavia, caso surjam alterações na metodologia de apuração do resultado, ou necessidade de diferenciação dos limites por esfera de governo "em razão de instabilidade econômica ou alterações nas políticas monetária ou cambial", o Presidente poderá solicitar revisão nos limites já fixados (BRASIL, 2000, art. 30).

Apesar da publicação da Resolução n. ${ }^{\circ} 40$ ter sido realizada em 2001, ficou estabelecido em seu art. $4^{\circ}$ que os estados, municípios e o Distrito Federal terão o "período compreendido entre a data da publicação desta Resolução e o final do décimo quinto exercício financeiro" para adequar os excedentes da dívida, reduzindo-os no mínimo 1/15 a cada exercício (SENADO FEDERAL, 2001, art. $4^{\circ}$ ). Todavia, ainda no mesmo parágrafo, a Resolução dispõe que os limites fiscais já serão aplicados em qualquer estado que (SENADO FEDERAL, 2001, art. $4^{\circ}$ ):

a) apresente relação entre o montante da dívida consolidada líquida e a receita corrente líquida inferior a esses limites, no final do exercício de publicação desta Resolução; e

b) atinja o limite previsto no art. $3^{\circ}$ antes do final do período de ajuste de 15 (quinze) exercícios financeiros.

Como sanção ao não cumprimento das medidas de redução do excesso da dívida ao longo do período de ajuste, o ente ficará impedido de contratar operações de créditos (SENADO FEDERAL, 2001, art. $5^{\circ}$ ). Entendeu-se que tal sanção visa conter o aumento do grau de endividamento dos entes, além disciplinar o uso racional do capital de terceiros. Entretanto, algumas questões sociais, como investimentos em infraestrutura, podem ser prejudicadas por falta de recursos no curto prazo.

Dessa forma, a quantia que ultrapassar o limite no quadrimestre deverá ter o seu excesso eliminado nos três quadrimestres subsequentes, sendo que $25 \%$ deverão ser eliminados no primeiro quadrimestre (BRASIL, 2000, art. 31).

O acompanhamento do cumprimento dos limites fiscais dá-se por meio do Relatório de Gestão Fiscal (RGF) (SENADO FEDERAL, 2001, art. 4º, II). O RGF é o relatório que objetiva "dar transparência à gestão fiscal do titular do Poder/órgão realizada no período" (STNb, 2014, p. 498). Dessa forma, a verificação dos cumprimentos dos limites fiscais é objeto de transparência na gestão pública.

Em seu anexo II, o RGF apresenta um demonstrativo destinado a apresentar informações pertinentes à $\mathrm{DC}$, às deduções, à $\mathrm{DCL}$, à RCL e ao percentual da DCL em

R. Cont. Ufba, Salvador-Ba, v. 9, n. 3, p. 64 - 82, set-dez 2015 
relação à RCL para fins de verificação dos limites (STNb, 2014). Assim sendo, tal demonstrativo permite a verificação do cumprimento do limite relativo à DCL. Por sua vez, o acompanhamento do montante da DC pode ser feito por meio do Balanço Patrimonial.

\subsection{Dívida dos Estados Brasileiros}

Para uma contextualização do cenário da dívida, buscou-se junto ao Sistema de Coleta de Dados Contábeis dos Entes da Federação (SISTN) (STN, 2014a) informações relativas à DCL dos estados brasileiros. Com isso, foi permitido visualizar a situação do cumprimento dos limites fiscais entre todos os entes da esfera estadual. A Tabela 1 apresenta as informações sobre a relação DCL/RCL dos estados e do Distrito Federal.

Tabela 1 - Relação DCL/RCL dos estados brasileiros e do Distrito Federal

\begin{tabular}{|c|c|c|c|c|c|c|c|c|c|c|c|c|c|c|c|c|}
\hline Região & UF & 2000 & 2001 & 2002 & 2003 & 2004 & 2005 & 2006 & 2007 & 2008 & 2009 & 2010 & 2011 & 2012 & 2013 & Média [3] \\
\hline \multirow{8}{*}{ 䒿 } & $\mathrm{AC}$ & 1,04 & 0,83 & 0,73 & 0,68 & 0,62 & 0,45 & 0,52 & 0,41 & 0,28 & 0,37 & 0,54 & 0,50 & 0,58 & 0,69 & 0,59 \\
\hline & $\mathrm{AM}$ & 1,00 & 0,69 & 0,67 & 0,56 & 0,45 & 0,37 & 0,33 & 0,19 & 0,13 & 0,24 & 0,27 & 0,19 & 0,15 & 0,22 & 0,39 \\
\hline & AP & 0,05 & 0,05 & 0,28 & 0,28 & 0,23 & 0,11 & 0,11 & 0,10 & 0,04 & 0,11 & 0,18 & 0,12 & 0,18 & 0,26 & 0,15 \\
\hline & PA & 0,57 & 0,63 & 0,67 & 0,61 & 0,60 & 0,46 & 0,44 & 0,35 & 0,28 & 0,24 & 0,29 & 0,19 & 0,11 & 0,10 & 0,40 \\
\hline & RO & 1,11 & 1,05 & 1,45 & 1,21 & 1,03 & 0,85 & 0,72 & 0,64 & 0,50 & 0,53 & 0,54 & 0,50 & 0,45 & 0,62 & 0,80 \\
\hline & RR & 0,31 & 0,28 & 0,35 & 0,43 & 0,04 & 0,15 & 0,10 & $-0,13$ & $-0,13$ & 0,31 & 0,04 & $-0,10$ & 0,20 & 0,37 & 0,16 \\
\hline & TO & 0,35 & 0,27 & 0,37 & 0,26 & 0,35 & 0,14 & 0,13 & 0,08 & 0,10 & 0,11 & 0,16 & 0,21 & 0,21 & 0,26 & 0,21 \\
\hline & Média [1] & $\mathbf{0 , 6 3}$ & $\mathbf{0 , 5 4}$ & 0,65 & $\mathbf{0 , 5 8}$ & 0,47 & 0,36 & $\mathbf{0 , 3 4}$ & $\mathbf{0 , 2 3}$ & $\mathbf{0 , 1 7}$ & $\mathbf{0 , 2 7}$ & 0,29 & $\mathbf{0 , 2 3}$ & $\mathbf{0 , 2 7}$ & 0,36 & 0,39 \\
\hline \multirow{10}{*}{ 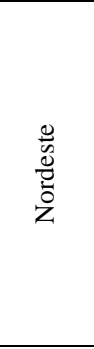 } & $\mathrm{AL}$ & 2,23 & 1,78 & 2,36 & 2,77 & 2,64 & 2,25 & 2,22 & 2,00 & 1,97 & 1,81 & 1,62 & 1,48 & 1,50 & 1,46 & 2,01 \\
\hline & BA & 1,64 & 1,71 & 1,82 & 1,63 & 1,42 & 1,17 & 1,02 & 0,82 & 0,72 & 0,63 & 0,52 & 0,46 & 0,49 & 0,47 & 1,04 \\
\hline & $\mathrm{CE}$ & 0,87 & 0,94 & 1,18 & 1,06 & 0,92 & 0,73 & 0,60 & 0,38 & 0,24 & 0,17 & 0,28 & 0,29 & 0,28 & 0,29 & 0,59 \\
\hline & MA & 2,58 & 2,10 & 2,73 & 2,22 & 1,74 & 1,33 & 1,15 & 0,91 & 0,74 & 0,68 & 0,64 & 0,47 & 0,41 & 0,38 & 1,29 \\
\hline & PB & 1,53 & 1,10 & 1,42 & 1,17 & 1,08 & 0,89 & 0,76 & 0,60 & 0,48 & 0,34 & 0,36 & 0,25 & 0,26 & 0,27 & 0,75 \\
\hline & PE & 0,86 & 1,12 & 1,25 & 1,17 & 1,04 & 0,83 & 0,67 & 0,53 & 0,42 & 0,43 & 0,38 & 0,39 & 0,46 & 0,53 & 0,72 \\
\hline & PI & 1,73 & 1,74 & 1,64 & 1,52 & 1,42 & 1,09 & 0,85 & 0,78 & 0,60 & 0,60 & 0,54 & 0,57 & 0,50 & 0,59 & 1,01 \\
\hline & $\mathrm{RN}$ & 0,71 & 0,54 & 0,65 & 0,53 & 0,38 & 0,32 & 0,26 & 0,22 & 0,19 & 0,17 & 0,20 & 0,13 & 0,11 & 0,15 & 0,33 \\
\hline & SE & 0,88 & 0,78 & 0,73 & 0,68 & 0,65 & 0,45 & 0,57 & 0,42 & 0,22 & 0,27 & 0,33 & 0,43 & 0,53 & 0,55 & 0,54 \\
\hline & Média [1] & 1,45 & 1,31 & $\mathbf{1 , 5 3}$ & 1,42 & 1,25 & 1,01 & $\mathbf{0 , 9 0}$ & 0,74 & 0,62 & $\mathbf{0 , 5 7}$ & 0,54 & $\mathbf{0 , 5 0}$ & $\mathbf{0 , 5 0}$ & $\mathbf{0 , 5 2}$ & 0,92 \\
\hline \multirow{5}{*}{$\begin{array}{l}\frac{0}{0} \\
\frac{0}{0} \\
\tilde{E} \\
\tilde{n}\end{array}$} & ES & 0,98 & 0,83 & 1,16 & 1,02 & 0,73 & 0,44 & 0,34 & 0,19 & 0,10 & 0,08 & 0,17 & 0,14 & 0,15 & 0,21 & 0,47 \\
\hline & MG & 1,41 & 2,34 & 2,63 & 2,43 & 2,24 & 2,03 & 1,89 & 1,88 & 1,76 & 1,79 & 1,82 & 1,82 & 1,75 & 1,83 & 1,97 \\
\hline & RJ & 2,07 & 1,90 & 2,35 & 2,01 & 2,04 & 1,90 & 1,72 & 1,73 & 1,60 & 1,63 & 1,56 & 1,46 & 1,65 & 1,54 & 1,80 \\
\hline & SP & 1,93 & 1,97 & 2,27 & 2,24 & 2,23 & 1,97 & 1,89 & 1,71 & 1,63 & 1,50 & 1,53 & 1,46 & 1,54 & 1,42 & 1,81 \\
\hline & Média [1] & 1,60 & 1,76 & 2,10 & 1,93 & $\mathbf{1 , 8 1}$ & 1,59 & 1,46 & $\mathbf{1 , 3 8}$ & 1,27 & 1,25 & 1,27 & 1,22 & 1,27 & 1,25 & 1,51 \\
\hline \multirow{4}{*}{$\bar{\Xi}$} & PR & 1,29 & 1,34 & 1,24 & 1,05 & 1,08 & 1,29 & 1,26 & 1,16 & 1,19 & 1,12 & 0,89 & 0,76 & 0,60 & 0,60 & 1,06 \\
\hline & RS & 2,66 & 2,51 & 2,79 & 2,80 & 2,83 & 2,58 & 2,53 & 2,54 & 2,34 & 2,20 & 2,14 & 2,14 & 2,18 & 2,09 & 2,45 \\
\hline & $\mathrm{SC}$ & 1,83 & 1,45 & 1,95 & 1,67 & 1,64 & 1,19 & 1,09 & 0,90 & 0,77 & 0,61 & 0,63 & 0,46 & 0,41 & 0,48 & 1,08 \\
\hline & Média [1] & 1,93 & 1,77 & 1,99 & 1,84 & $\mathbf{1 , 8 5}$ & 1,69 & 1,63 & $\mathbf{1 , 5 3}$ & 1,43 & 1,31 & 1,22 & 1,12 & 1,06 & 1,06 & $\mathbf{1 , 5 3}$ \\
\hline \multirow{5}{*}{$\begin{array}{l}0 \\
0 \\
0 \\
0 \\
\vdots \\
0 \\
0 \\
0 \\
0\end{array}$} & DF & 0,36 & 0,35 & 0,40 & 0,36 & 0,28 & 0,35 & 0,33 & 0,19 & 0,16 & 0,17 & 0,18 & 0,16 & 0,10 & 0,16 & 0,25 \\
\hline & GO & 3,13 & 2,81 & 2,77 & 2,40 & 2,21 & 1,85 & 1,82 & 1,61 & 1,40 & 1,28 & 1,30 & 1,01 & 1,02 & 0,92 & 1,82 \\
\hline & MS & 3,10 & 2,94 & 3,10 & 2,67 & 2,33 & 2,01 & 1,81 & 1,48 & 1,15 & 1,15 & 1,20 & 1,13 & 1,05 & 1,02 & 1,87 \\
\hline & MT & 2,50 & 1,97 & 1,59 & 1,76 & 1,30 & 1,11 & 1,10 & 0,94 & 0,70 & 0,54 & 0,55 & 0,40 & 0,30 & 0,35 & 1,08 \\
\hline & Média [1] & 2,27 & 2,02 & 1,97 & 1,80 & $\mathbf{1 , 5 3}$ & 1,33 & 1,27 & $\mathbf{1 , 0 6}$ & $\mathbf{0 , 8 5}$ & $\mathbf{0 , 7 9}$ & $\mathbf{0 , 8 1}$ & 0,68 & 0,62 & 0,61 & 1,26 \\
\hline \multicolumn{2}{|c|}{ Média Nacional [2] } & 1,43 & 1,33 & $\mathbf{1 , 5 0}$ & 1,38 & 1,24 & 1,05 & 0,97 & 0,84 & 0,73 & 0,71 & 0,70 & 0,63 & 0,64 & 0,66 & 0,99 \\
\hline
\end{tabular}

Nota: [1] Média anual da região; [2] Média nacional é igual a média anual dos estados e do Distrito Federal; e [3] Média da série histórica de cada estado, Distrito Federal, média da região e média nacional.

Fonte: Adaptado STN (2014a).

Dessa forma, a Tabela 1 demonstra a relação DCL/RCL de todos os estados e do Distrito Federal, além da média simples dos entes dentro do mesmo ano, bem como a média 
simples do ente ao longo da série histórica utilizada. A análise e a contextualização desses valores com os dados de Santa Catarina serão apresentadas na seção 4.3.

\subsection{Pesquisas anteriores}

O intuito desta seção é descrever algumas pesquisas obtidas em publicações acadêmico-científicas que possuem relação ao tema/problema central desta pesquisa. $\mathrm{O}$ resultado da pesquisa por trabalhos relacionados é apresentado no quadro a seguir, em que são elencadas suas fontes de publicação, sem o intuito de exaurir todos os aspectos.

\begin{tabular}{|c|c|c|}
\hline Autores [1] & $\begin{array}{l}\text { Título / Tipo de } \\
\text { publicação [2] }\end{array}$ & Temática abordada e resultados encontrados \\
\hline $\begin{array}{l}\text { Machado e } \\
\text { Mello (2011) }\end{array}$ & $\begin{array}{l}\text { "A Lei Responsabilidade } \\
\text { Fiscal e o impacto sobre o } \\
\text { endividamento dos municípios } \\
\text { paranaenses" / Evento }\end{array}$ & $\begin{array}{l}\text { "O objetivo deste trabalho é verificar a situação do endividamento dos } \\
\text { Municípios Paranaenses após a implantação da LRF, no que diz respeito } \\
\text { a sua redução e cumprimentos dos limites, mais especificamente, se } \\
\text { ocorreram mudanças significativas no endividamento dos Municípios } \\
\text { Paranaenses após a implantação da LRF e se eles cumpriram com os } \\
\text { limites de endividamento estabelecido." / "[...] foram utilizados } \\
\text { indicadores propostos no relatório de Gestão Fiscal da própria LRF e na } \\
\text { literatura, todos já testados em trabalhos anteriores." / ". Após aplicação } \\
\text { dos testes e análises dos resultados, conclui-se que os Municípios } \\
\text { Paranaenses cumpriram com os limites estabelecidos na LRF e após o } \\
\text { seu vigor, } 94 \% \text { diminuíram o endividamento." }\end{array}$ \\
\hline Queiroz (2012) & $\begin{array}{l}\text { "Pacto de austeridade fiscal: } \\
\text { um diagnóstico da dívida } \\
\text { consolidada líquida dos } \\
\text { municípios do estado de } \\
\text { Pernambuco entre os anos de } \\
2006 \text { a 2010" / Tese }\end{array}$ & $\begin{array}{l}\text { "O objetivo deste estudo é identificar o comportamento da Dívida } \\
\text { Consolidada Líquida dos municípios do Estado de Pernambuco nos } \\
\text { anos de } 2006 \text { a } 2010 . " \text { / "O estudo preliminarmente mostra ao agrupar } \\
\text { os municípios do Estado que entre os anos de } 2006 \text { a } 2010 \text { houve um } \\
\text { aumento expressivo do endividamento na ordem de } 60,34 \% \text {." / "Por } \\
\text { fim, preliminarmente o estudo mostra que dos } 185 \text { municípios de } \\
\text { Pernambuco analisados apenas } 1,62 \% \text { geraram resultado nominal em } \\
\text { todos os anos analisados, enquanto } 98,38 \% \text { não conseguiram cumprir a } \\
\text { meta em um ou mais anos estabelecida na LDO e LRF." }\end{array}$ \\
\hline $\begin{array}{l}\text { Messias Silva, } \\
\text { Lopes, } \\
\text { Pederneiras e } \\
\text { Paulo (2012) }\end{array}$ & $\begin{array}{l}\text { "Dez anos de responsabilidade } \\
\text { fiscal: um estudo da evolução } \\
\text { da dívida pública da Prefeitura } \\
\text { do Recife" / Periódico }\end{array}$ & $\begin{array}{l}\text { "Este artigo teve como objetivo analisar como se comportou o } \\
\text { endividamento do município de Recife, ante a obediência à Lei de } \\
\text { Responsabilidade Fiscal, depois de dez anos de sua edição." / "O estudo } \\
\text { analisou as demonstrações contábeis do ente municipal, exigidas pela } \\
\text { Lei } \mathrm{n}^{\circ} 4.320 / 1964 \text { e pela Lei Complementar } \mathrm{n}^{\circ} 101 / 2000 \text {, que se } \\
\text { encontram disponíveis na Internet. Os resultados revelam que o } \\
\text { endividamento municipal manteve-se constante ao longo da série } \\
\text { estudada e que não houve mudanças significativas [...]" }\end{array}$ \\
\hline $\begin{array}{l}\text { Mello e } \\
\text { Dalchiavo } \\
(2012)\end{array}$ & $\begin{array}{l}\text { "A Lei de Responsabilidade } \\
\text { Fiscal (LRF) e o impacto sobre } \\
\text { o endividamento dos } \\
\text { municípios potiguares" / } \\
\text { Periódico }\end{array}$ & $\begin{array}{l}\text { "[...] o propósito deste artigo é verificar a situação das finanças dos } \\
\text { Municípios Potiguares após a implantação da LRF no que diz respeito à } \\
\text { redução de endividamento e ao cumprimento dos seus limites." / "Com } \\
\text { o intuito de examinar se os Municípios Potiguares cumpriram com os } \\
\text { limites estabelecidos, foi analisado o período de } 2001 \text { a } 2009 \text {, em que os } \\
\text { resultados dos indicadores de endividamento foram comparados com os } \\
\text { seus respectivos limites. As evidências indicam que a LRF pode ter } \\
\text { cumprido com seu objetivo de controlar o avanço do endividamento }\end{array}$ \\
\hline
\end{tabular}


mediante a fixação de regras e limites."

Notas: [1] Autores dispostos em ordem cronológica das publicações citadas; [2] Os tipos de publicações, sinteticamente, são: Tese; Periódico; e Evento. Detalhadamente, são: Tese - Teses de doutorado (strictu sensu). Periódico - Artigos técnicocientíficos publicados em periódicos (revistas, boletins, etc.). Evento - Artigos técnico-científicos publicados em anais de eventos (congressos, encontros, etc.).

Fonte: Elaborado pelos autores com base nas fontes citadas.

Observa-se neste quadro que os trabalhos buscaram, de forma geral, evidenciar o cumprimento dos limites fiscais para a DCL. Apesar dos trabalhos encontrados abordarem o comportamento da dívida pública perante os limites fiscais do Senado, possuem estudos no âmbito da esfera municipal.

No entanto, nenhum dos referidos trabalhos assemelharam-se a esta pesquisa quanto ao objetivo. Apesar disso, apresentam objetos semelhantes, visto que as pesquisas similares encontradas buscam verificar comportamento da dívida pública de um ou mais entes quanto aos limites fiscais. Também foram encontrados outros trabalhos com abordagem metodológica ou objeto semelhantes. Contudo, tais pesquisas não apresentaram similaridade com o tema aqui abordado e por isso não foram mencionadas.

\section{PROCEDIMENTOS METODOLÓGICOS}

Com a finalidade de alcançar o objetivo proposto, bem como responder à perguntaproblema formulada nesta pesquisa, foi elaborado um planejamento metodológico para aplicação do estudo. Inicia-se com a classificação da pesquisa, dentro de alguns tipos que indicam em que situação é enquadrada. Após, é apresentada a entidade estudada. Por fím, são expostos os instrumentos utilizados e procedimentos empregados nos dados coletados e sua análise.

\subsection{Classificação da PESQUISA}

De acordo com a abordagem de Raupp e Beuren (2004), uma pesquisa na área da Ciência Contábil pode ser classificada em três categorias: quanto aos objetivos, se exploratória, descritiva e explicativa; quanto aos procedimentos utilizados, se trata de estudo de caso, levantamento, pesquisa bibliográfica, documental, participante e experimental; e quanto à abordagem do problema, com caráter quantitativo e/ou qualitativo. Em consonância a tipologia apresentada, segue a classificação desta pesquisa, conforme cada aspecto.

Conforme o objetivo, esta pesquisa é classificada como descritiva, por utilizar-se como procedimento técnico a análise de documentos públicos, com vistas a identificar o cumprimento dos limites da Dívida Consolidada Líquida (DCL) em um determinado período.

Quanto aos procedimentos utilizados, classifica-se esta pesquisa como bibliográfica e documental. Classifica-se como pesquisa documental por utilizar-se de documentos contábeis "que ainda não receberam um tratamento analítico" (RAUPP; BEUREN, 2004, p. 89), sendo as análises inéditas deste artigo. Também é considerada como pesquisa bibliográfica, por utilizar de doutrinas e outras pesquisas com o intuito de fundamentar e embasar a aplicação deste estudo.

Esta pesquisa, em função de apresentar etapas com abordagens quantitativas e qualitativas, pode ser considerada mista. A etapa quantitativa é predominante nesta pesquisa, e ocorre quando são coletados e tabulados dados contábeis sobre a DCL ao longo dos anos delimitados. Após a abordagem quantitativa, segue-se o estudo de forma qualitativa em busca da interpretação dos dados organizados na primeira etapa, bem como do entendimento e compreensão dos dados ilustrados em tabelas e gráficos.

\subsection{Entidade Estudada}

R. Cont. Ufba, Salvador-Ba, v. 9, n. 3, p. 64 - 82, set-dez 2015 
O enfoque desta pesquisa é o estudo de um estado brasileiro. Diante dos vinte e seis estados, além de um Distrito Federal, foi escolhido apenas um deles como objeto de estudo. Devido à dimensão territorial do Brasil e as características peculiares socioeconômicas de cada região, nem todo o resultado encontrado neste estudo se aplica em sua totalidade aos demais estados e ao Distrito Federal.

Apesar da característica própria do ente abordado na pesquisa, por tratar-se de um estado dentro da Federação, o mesmo necessita enquadrar-se e seguir a legislação aplicada aos demais. Então, no quesito do cumprimento legal, todos os estados brasileiros estão sob a regência de uma mesma normatização nacional que os trata de forma igualitária. Visto isso, em outro momento, pode-se buscar a aplicação da abordagem desta pesquisa em outros estados.

A abordagem deu-se sobre o Estado de Santa Catarina, cujo limite da DCL foi o objeto de estudo. A facilidade em ter acesso às informações necessárias para a pesquisa foi um dos fatores pela escolha desse ente para o estudo de caso. Adicionalmente, houve interesse dos pesquisadores pelo Estado em função de ser onde residem, por isso, já estão familiarizados com o contexto socioeconômico local. Na seção 4.1 consta a apresentação do Estado de Santa Catarina.

\subsection{Instrumentos e Procedimentos da Pesquisa}

Esta pesquisa apresentou um ente público como objeto para análise de problema proposto. A referida análise encontra-se no capítulo 4 (Resultados da pesquisa), no qual também são apresentados os dados e os instrumentos contábeis que permitiram chegar às conclusões.

Os documentos escolhidos para serem utilizados na pesquisa, como fontes primárias, foram os demonstrativos contábeis sobre a DCL presentes nos Relatórios de Gestão Fiscal (RGF) do Estado de Santa Catarina, referentes aos anos de 2000 a 2013, além das normas vigentes sobre dívida pública. A coleta dos demonstrativos contábeis foi realizada junto ao sitio eletrônico da Secretaria Estadual da Fazenda, complementadas com consultas por correspondência eletrônica com a Gerência de Informações Contábeis, subordinada à Diretoria de Contabilidade Geral do Estado de Santa Catarina. Por sua vez, a coleta das normas vigentes foi realizada por meio de consulta ao acervo digital do Palácio do Planalto e do Senado Federal.

Como fontes secundárias (pesquisa bibliográfica) foram utilizados livros, artigos científicos e trabalhos acadêmicos com o intuito de dar embasamento e fundamentação aos argumentos e conclusões apresentadas no resultado da pesquisa. Foram adotados dois critérios para a utilização da bibliografia consultada para elaboração do capítulo 2 (Fundamentação teórica): livros especializados já consagrados na área da Contabilidade Pública; e artigos científicos e trabalhos acadêmicos que retratam o tema similar ao desta pesquisa.

Para atingir os resultados da pesquisa, foram adotados os seguintes procedimentos:

Passo 1: Realizar revisão de literatura sobre Contabilidade Pública, com enfoque sobre a dívida, visando identificar as exigências normativas existentes e aplicáveis aos estadosmembros.

Passo 2: Obter acesso aos relatórios contábeis do Estado de Santa Catarina, em especial ao RGF referente aos anos de 2000 a 2013, por meio do portal da Secretaria do Estado da Fazenda na internet ou outros meios disponíveis.

Passo 3: A partir dos demonstrativos obtidos, identificar, extrair e organizar os dados que evidenciassem os limites fiscais sobre a DCL do Estado de Santa Catarina. 
Passo 4: Realizar ajustes necessários nos dados, incluindo a atualização monetária mediante o emprego de um índice de preços. Foi escolhido o Índice Nacional de Preços ao Consumidor Amplo (IPCA), conforme critérios evidenciados na seção 4.2.

Passo 5: Apresentar os dados organizados e ajustados por meio de tabelas e gráficos, com vistas a evidenciar o cumprimento ou descumprimento dos limites fiscais incidentes sobre a DCL.

Passo 6: Analisar os dados contidos em gráficos e tabelas, observando e comparando os valores obtidos no período de estudo, com vistas a permitir uma conclusão sobre o cumprimento ou não dos limites fiscais.

\section{RESULTADOS DA PESQUISA}

\subsection{Apresentação do Estado de Santa Catarina}

As expedições ao Estado de Santa Catarina iniciaram-se por volta do ano de 1515, mas nessa época eram apenas expedições ao sul do país, sendo que seu povoamento deu-se a partir de 1637 por meio dos bandeirantes, que inicialmente povoaram a futura capital: Nossa Senhora do Desterro, posteriormente chamada de Florianópolis (SC, 2014c).

Localizado no sul do Brasil, o Estado de Santa Catarina é um dos integrantes da Região Sul, fazendo divisas com o Estado do Paraná ao norte, e ao sul com o Estado do Rio Grande do Sul (SC, 2014a). Ao leste, Santa Catarina é banhada pelo Oceano Atlântico, e a oeste faz fronteira com a Argentina. (SC, 2014a).

Sua colonização foi, predominantemente, realizada por imigrantes europeus, em sua maioria portugueses açorianos, alemães e italianos, no século XIX (SC, 2014a). Posteriormente, foi colonizado por gaúchos de origem italiana e alemã, no século XX (SC, 2014a). Segundo o Instituto Brasileiro de Geografia e Estatística (IBGE, 2014), a população estimada no ano de 2010 era de 6,6 milhões de habitantes, distribuídos em seus 295 municípios, tendo sua capital administrativa sediada no Município de Florianópolis.

O Estado de Santa Catarina apresenta diferentes formas de relevo, e particularidades climáticas e coloniais as quais possibilitam que tenha diferentes atividades econômicas (SC, 2014b). Pode-se destacar como algumas de suas atividades econômicas: turismo, indústria têxtil, agroindustrial, indústria naval, indústria moveleira, indústria de papel, celulose e madeira, carbonífera e cerâmica (SC, 2014b).

O Estado de Santa Catarina é o $20^{\circ}$ estado em extensão territorial no Brasil, com 95 mil km² (SC, 2014a). Segundo o IBGE (2012), o Produto Interno Bruto (PIB) catarinense no ano de 2012 era o sexto maior do Brasil, registrando valores de R \$ 177,2 bilhões. Além disso, o Estado foi o sétimo estado-membro que mais arrecadou tributos entre os anos de 2000 e 2013 (SRFB, 2015). O Estado aparece em terceiro lugar no Índice de Desenvolvimento Humano Municipal (IDHM) (PNUD, 2010).

\subsection{Obtenção, Coleta e Ajuste dos Dados}

Para a realização desta pesquisa, buscou-se junto ao órgão competente os Relatórios de Gestão Fiscal (RGF) do Estado de Santa Catarina referentes aos terceiros quadrimestres dos anos de 2000 a 2013. Com isso, foram utilizados os dados mais recentes do RGF, visto que houve anos em que os valores do terceiro quadrimestre foram alterados.

As consultas foram realizadas no sítio eletrônico da Secretaria do Estado da Fazenda de Santa Catarina, complementadas por meio de trocas de mensagens eletrônicas (e-mails) com o órgão, haja vista a falta da publicação, na internet, dos RGF referentes aos anos de 2000 e 2001.

R. Cont. Ufba, Salvador-Ba, v. 9, n. 3, p. 64 - 82, set-dez 2015 
O RGF é um dos relatórios previstos na Lei de Responsabilidade Fiscal (LRF), considerado um instrumento de transparência (BRASIL, 2000, art. 48). Está contido no RGF o demonstrativo utilizado para observar os limites fiscais da Dívida Consolidada Líquida (DCL) (BRASIL, 2000, art. 55, I, b).

O ajuste monetário dos dados coletados foi entendido como necessário para minimizar as distorções causadas pela inflação na análise de evolução dos valores monetários. Dessa forma, é possível comparar valores divulgados em anos distantes sem que a inflação inviabilize a análise.

Para tal ajuste, foi adotado o Índice Nacional de Preços ao Consumidor Amplo (IPCA), índice de inflação oficial do país, utilizado pelo Banco Central do Brasil (BACEN) para a verificação do cumprimento da meta inflacionária (BACEN, 2013). É de responsabilidade do IBGE a apuração mensal do IPCA desde o ano de 1980 (IBGE, 2013).

Por tratar-se do índice oficial de inflação no Brasil, o IPCA foi escolhido como o índice de correção da série história desta pesquisa, quando o assunto abordado for a evolução das contas presentes nos demonstrativos contábeis. No entanto, ao tratar-se dos limites fiscais fixados pelo Senado Federal, os valores apresentados são originais, ou seja, sem ajuste monetário, visto que o limite fiscal é representado por relações percentuais entre as variáveis.

\subsection{Análise do Cumprimento dos Limites}

Para realizar a análise do cumprimento dos limites, organizou-se em uma única planilha eletrônica os dados dos grupos de contas presentes nos demonstrativos constantes nos RGF, referentes aos anos de 2000 e 2013.

A Tabela 2 apresenta os valores da Receita Corrente Líquida (RCL), da DCL, do PIB de Santa Catarina, além de relacionar a DCL tanto com a RCL (para verificação do limite fiscal) e também a DCL com o PIB.

Tabela 2 - Relação DCL, RCL e PIB do Estado de Santa Catarina - 2000 a 2013

Valores originais em $\mathrm{R} \$$ milhões.

\begin{tabular}{|c|c|c|c|c|c|}
\hline Ano & DCL [a] & RCL [b] & DCL/RCL [c] & PIB [d] & DCL/PIB [e] \\
\hline 2000 & 6.018 & 3.288 & $183 \%$ & 42.428 & $14 \%$ \\
\hline 2001 & 5.681 & 3.904 & $145 \%$ & 46.535 & $12 \%$ \\
\hline 2002 & 8.511 & 4.374 & $195 \%$ & 55.732 & $15 \%$ \\
\hline 2003 & 8.555 & 5.130 & $167 \%$ & 66.849 & $13 \%$ \\
\hline 2004 & 9.324 & 5.669 & $164 \%$ & 77.393 & $12 \%$ \\
\hline 2005 & 8.020 & 6.719 & $119 \%$ & 85.316 & $9 \%$ \\
\hline 2006 & 8.031 & 7.377 & $109 \%$ & 93.147 & $9 \%$ \\
\hline 2007 & 7.678 & 8.498 & $90 \%$ & 104.623 & $7 \%$ \\
\hline 2008 & 8.066 & 10.421 & $77 \%$ & 123.282 & $7 \%$ \\
\hline 2009 & 6.312 & 10.406 & $61 \%$ & 129.806 & $5 \%$ \\
\hline 2010 & 7.464 & 11.858 & $63 \%$ & 152.482 & $5 \%$ \\
\hline 2011 & 6.298 & 13.791 & $46 \%$ & 169.050 & $4 \%$ \\
\hline 2012 & 5.899 & 14.535 & $41 \%$ & 177.276 & $3 \%$ \\
\hline 2013 & 7.615 & 15.893 & $48 \%$ & - & - \\
\hline
\end{tabular}

Notas: [a] DCL - Dívida Consolidada Líquida; [b] RCL - Receita Corrente Líquida; [c] Relação entre DCL e RCL para verificação do limite fiscal; [d] PIB - Produto Interno Bruto de Santa Catarina - não há dados do ano de 2013; [e] Relação entre DCL e PIB, exceto ano de 2013, por falta de dados do PIB.

Fonte: Elaborado pelos autores com base nos Relatórios de Gestão Fiscal (SC, 2000 e 2001; 2002 a 2013) e IBGE (2002 e 2012).

É possível observar na Tabela 2, que o Estado de Santa Catarina já respeitava o limite fiscal estabelecido na Resolução n. ${ }^{\circ}$ 40/2001 desde o ano de 2000. Logo, desde a data da publicação da referida norma, o Estado já teve que continuar respeitando o limite estabelecido, caso contrário passaria a sofrer as sanções, indicadas na LRF. 
Desde que foi publicada a Resolução, o Estado apresentou apenas um ano (2002) como crítico, no qual se aproximou do limite de $200 \%$ da RCL. Nesse ano, a relação DCL/RCL ficou em 195\%, ou seja, 5 p.p. abaixo do limite fiscal.

Para efeitos de comparação, foi apurada também a relação DCL/PIB na série histórica estudada até o ano de 2012, visto que os dados de 2013 não haviam sido divulgados até o momento de conclusão deste artigo. Foi apurada tal relação para verificar a representatividade da DCL na economia do Estado.

Dessa forma, pode-se verificar que a relação DCL/PIB diminuiu de 2000 para 2001 (de 14\% para 12\%), em seguida aumentou em 2002 (para 15\%), mesmo ano em que a relação DCL/RCL também aumentou (para 195\%). Contudo, observa-se na Tabela 2 uma substancial redução de ambas as relações entre os anos de 2002 e 2012 (DCL/RCL de 195\% para 41\%; DCL/PIB de $15 \%$ para 3\%). O Gráfico 1 ilustra o cumprimento do limite fiscal do Estado de Santa Catarina na série estudada.

R. Cont. Ufba, Salvador-Ba, v. 9, n. 3, p. 64 - 82, set-dez 2015 
Gráfico 1 - Relação DCL e RCL do Estado de Santa Catarina - 2000 a 2013

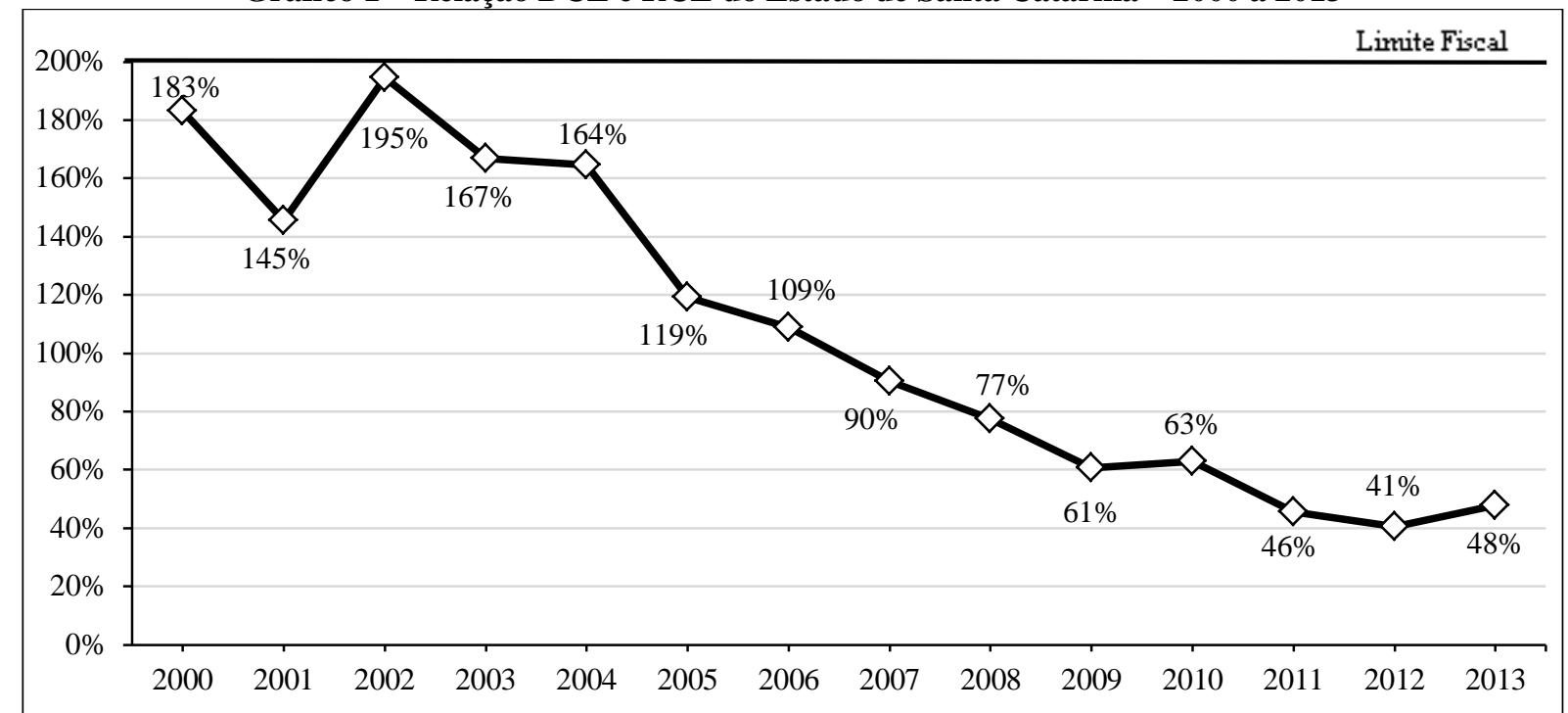

Fonte: Elaborado pelos autores com base nos Relatórios de Gestão Fiscal (SC, 2000 e 2001; 2002 a 2013 ).

Nota-se que de 2002 em diante a relação da DCL passou a diminuir consideravelmente ano a ano, apenas com os anos de 2010 e 2013 com aumentos (R \$ 1,2 bilhão e R \$ 1,7 bilhão, respectivamente). Existem três fatores para que a relação DCL/RCL diminua: (i) DCL diminuir; (ii) RCL aumentar; e (iii) DCL diminuir e RCL aumentar concomitantemente.

Observa-se no Gráfico 1 que a partir do ano de 2007 o limite fiscal do Estado de Santa Catarina ficou abaixo de $100 \%$. Isso se justifica pelo fato de que a partir do ano de 2007 a RCL ultrapassou a DCL, e essa diferença foi aumentando ao longo dos anos subsequentes.

Em comparação com os demais estados da Federação (Tabela 1), nota-se que o Estado de Santa Catarina esteve abaixo da média dos estados da Região Sul em todos os anos analisados. Quando comparado com a média nacional, o Estado apresentou menor relação DCL/RCL a partir do ano de 2009 (61\% contra 71\% da média nacional). Em todos os anos entre 2000 e 2008, a relação DCL/RCL do Estado esteve acima da média nacional.

\subsection{Análise da Evolução da Dívida}

Busca-se nesta seção analisar a evolução da DCL, RCL e PIB com dados atualizados monetariamente. Isso se justifica para que a série histórica não tenha seus valores distorcidos pela ocorrência da inflação.

A Tabela 3 demonstra a Dívida Consolidada (DC), DCL, RCL e PIB atualizados pelo IPCA. Não se considerou pertinente apresentar a relação DCL/RCL atualizada pela inflação, visto que o cumprimento dos limites fiscais torna-se pertinente pelos valores absolutos, e publicados no ano em que foram prestadas contas. Por outro lado, criou-se a relação DC/PIB para verificar a representatividade da dívida perante o PIB, sem os descontos.

Assim como a Tabela 2, a Tabela 3 apresenta uma variável de dívida em relação ao PIB, mas desta vez analisou-se o quociente DC/PIB em valores atualizados monetariamente. Dessa forma, verificou-se a representatividade da DC estadual, sem os descontos aplicados na apuração da DCL. 
Tabela 3 - Dívidas, RCL e PIB do Estado de Santa Catarina - 2000 a 2013

Valores em R\$ milhões, atualizados monetariamente pelo IPCA até 31/12/2013.

\begin{tabular}{c|r|r|r|r|r}
\hline Ano & DC [a] & DCL [b] & RCL [c] & PIB [d] & DC/PIB [e] \\
\hline 2000 & 13.964 & 13.638 & 7.671 & 98.980 & $14 \%$ \\
2001 & 13.185 & 11.957 & 8.526 & 101.633 & $13 \%$ \\
2002 & 16.467 & 15.919 & 8.679 & 110.580 & $15 \%$ \\
2003 & 15.674 & 14.640 & 9.178 & 119.598 & $13 \%$ \\
2004 & 15.935 & 14.829 & 9.352 & 127.677 & $12 \%$ \\
2005 & 15.984 & 12.068 & 10.394 & 131.984 & $12 \%$ \\
2006 & 15.919 & 11.717 & 10.930 & 138.015 & $12 \%$ \\
2007 & 14.856 & 10.724 & 12.131 & 149.347 & $10 \%$ \\
2008 & 16.559 & 10.638 & 14.143 & 167.320 & $10 \%$ \\
2009 & 14.971 & 7.981 & 13.438 & 167.622 & $9 \%$ \\
2010 & 16.210 & 8.911 & 14.569 & 187.337 & $9 \%$ \\
2011 & 14.979 & 7.060 & 15.954 & 195.559 & $8 \%$ \\
2012 & 14.853 & 6.248 & 15.837 & 193.158 & $8 \%$ \\
2013 & 15.806 & 7.615 & 16.356 & N/D & - \\
\hline
\end{tabular}

Notas: [a] DC - Dívida Consolidada; [b] DCL - Dívida Consolidada Líquida; [c] RCL - Receita Corrente Líquida; [d] PIB Produto Interno Bruto com dados até 2012; [e] Relação DC e PIB.

Fonte: Elaborado pelos autores com base nos Relatórios de Gestão Fiscal (SC, 2000 e 2001; 2002 a 2013) e IBGE (2002 e 2012).

Conforme observado na Tabela 3, a DCL do Estado apresentou queda na série histórica estudada. Do ano de 2000 até 2013, seu valor foi reduzido em 44,2\%. Quando analisada a RCL, percebe-se que seu comportamento foi inverso ao que ocorreu com a DCL, aumentando em 113,2\% entre os anos 2000 e 2013.

É possível perceber que a DC não apresentou grandes variações de valores ao longo dos anos, e o PIB apresentou crescimento positivo em toda a série, com variação de $95 \%$ do ano de 2000 a 2012. Com isso, justifica-se o motivo da queda anual da relação DC/PIB (exceto no ano de 2002), uma vez que o numerador da relação manteve-se estável e o denominador apresentou aumento.

Gráfico 2 - DCL e RCL do Estado de Santa Catarina - 2000 a 2013

Valores em R\$ milhões, atualizados monetariamente pelo IPCA até 31/12/2013.

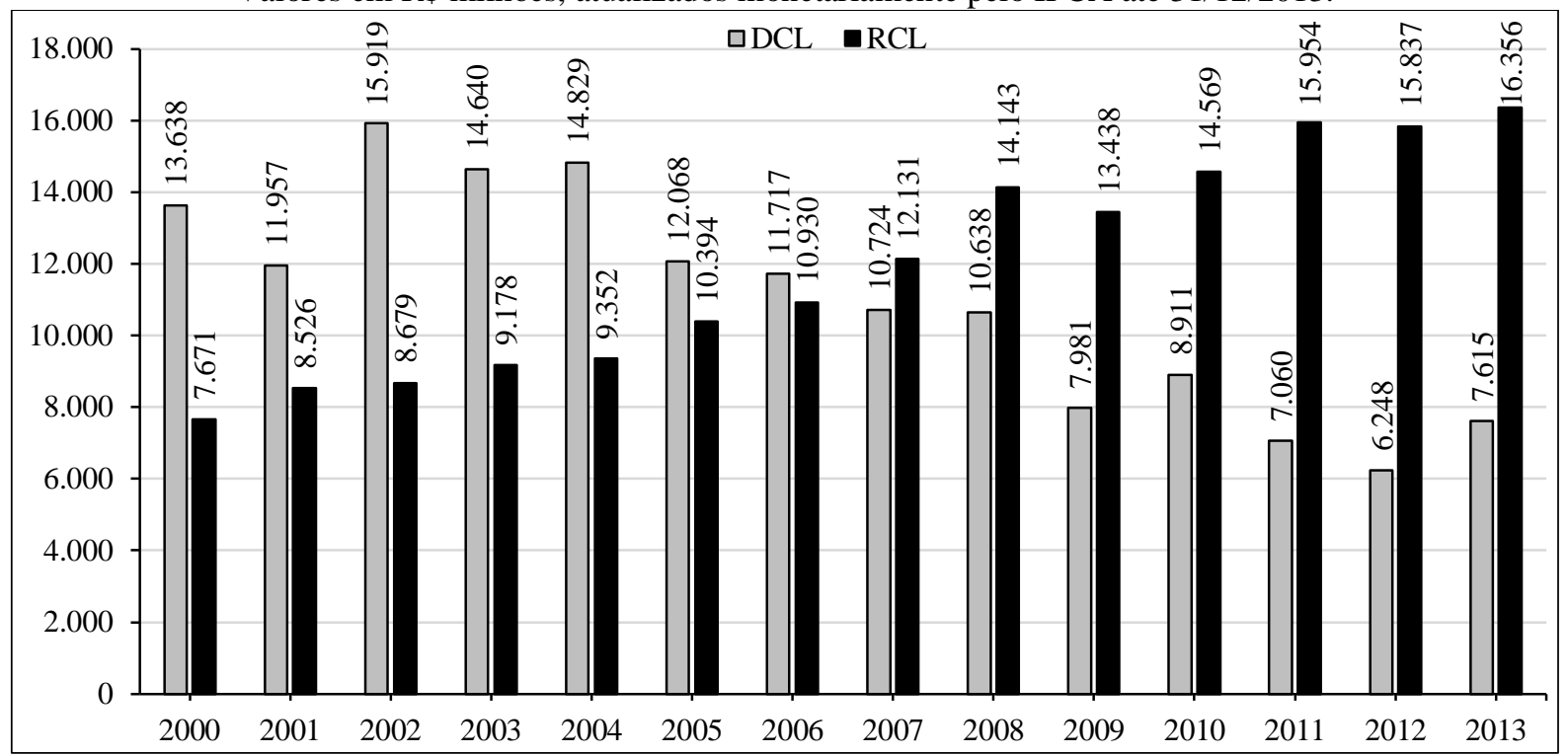

Fonte: Elaborado pelos autores com base nos Relatórios de Gestão Fiscal (SC, 2000 e 2001; 2002 a 2013).

O Gráfico 2 ilustra o comportamento inverso da DCL e da RCL. Enquanto a DCL apresentou comportamento de queda (salvo por exceções dentro do período), a RCL teve seus valores em crescente, ultrapassando os R $\$ 16$ bilhões no ano de 2013 , seu maior valor na 
série. Para a DCL, o ano de 2002 apresentou seu maior valor histórico (quase R \$ 16 bilhões), e o ano 2012, o menor valor (R $\$ 6,2$ bilhões).

\section{CONCLUSÕES}

A presente pesquisa apresentou como objetivo identificar se no Estado de Santa Catarina houve cumprimento dos limites fiscais relativos à Dívida Consolidada Líquida (DCL) entre os anos de 2000 e 2013. A partir da análise dos dados descritos no capítulo anterior, pode-se concluir que em toda a série histórica analisada o Estado cumpriu o limite fixado na Resolução n. ${ }^{\circ}$ 40/2001 do Senado Federal. Pode-se ainda verificar que a relação da DCL com a Receita Corrente Líquida (RCL) foi reduzida de $183 \%$ para $48 \%$ entre os anos de 2000 e 2013, o que representa 135 p.p. ou 74\% de diminuição. Tal redução decorreu da elevação da RCL e da diminuição da DCL ao longo da série.

Mesmo no ano anterior à entrada em vigor da Resolução n. ${ }^{\circ}$ 40/2001, o Estado teve sua DCL abaixo dos $200 \%$ da RCL. Dessa forma, as sanções normativas de descumprimento já passaram a valer para o Estado desde o início da vigência da Resolução.

Ressalta-se também que tanto a Dívida Consolidada (DC) quanto a DCL representaram pouca expressividade em relação ao PIB do Estado nos anos de 2000 a 2012 . A relação da DC/PIB diminuiu de $14 \%$ para $8 \%$, enquanto a relação DCL/PIB diminuiu de $14 \%$ para $3 \%$.

Em valores atualizados pela inflação, a DCL passou de R\$ 13,6 bilhões para R $\$ 7,6$ bilhões nos anos de 2000 a 2013, representando uma redução de $\mathrm{R} \$ 6,0$ bilhões. $\mathrm{O}$ ano de 2002 apresentou maior valor na série ( $\mathrm{R} \$ 15,9$ bilhões), e o ano de 2012 o de menor valor ( $\mathrm{R} \$$ 6,2 bilhões). A RCL teve comportamento inverso à DCL, iniciando a série com R $\$ 7,6$ bilhões no ano de 2000 e encerrando em 2013 com R\$ 16,4 bilhões de reais, com um aumento de $\mathrm{R} \$ 8,7$ bilhões.

Salvo exceções, pode-se concluir que o limite fiscal para a DCL, de duas vezes a RCL (200\%), não foi um valor frequentemente ultrapassado pelos estados-membros. Aparentemente, foi fixado um limite superior à necessidade dos entes para o mesmo não ser comumente ultrapassado. Em comparação com a Região Sul, percebeu-se que o Estado de Santa Catarina teve a média da relação DCL/RCL na série próxima à do Estado do Parará (108\% e 106\%, respectivamente). Contudo, o Estado do Rio Grande do Sul ficou acima do limite fiscal, com média de $245 \%$ na série. A média histórica do Estado de Santa Catarina (108\%) ficou acima da média nacional (99\%). Entretanto, tanto a média do Estado quanto a nacional esteve abaixo do limite do Senado Federal em toda a série.

Deste modo, considera-se que este artigo trouxe uma inovação com contribuição no cenário das pesquisas acadêmico-científicas, visto que teve como objeto de estudo os limites fiscais da DCL num ente da esfera estadual, diferentemente dos demais estudos encontrados, que tratavam da esfera municipal.

Como limitação do trabalho, pode-se destacar a origem dos dados analisados. Com exceção dos valores do PIB, os demais dados foram extraídos exclusivamente dos Relatórios de Gestão Fiscal do Poder Executivo, sem averiguar se todos já haviam sido aprovados pelo Tribunal de Contas do Estado de Santa Catarina. Além disso, outra limitação foi a falta de divulgação do valor do PIB do Estado referente ao ano de 2013, para poder analisar todos os quocientes abordados no mesmo horizonte temporal.

Para pesquisas futuras, sugere-se que sejam realizados trabalhos que visem procurar as causas históricas, econômicas e políticas, que fizeram a DCL diminuir e a RCL aumentar ao longo da série pesquisada, conforme evidenciado neste artigo. Dessa forma, encontrar-se-ão as justificativas para que a relação DCL/RCL tenha diminuído de $183 \%$ para $48 \%$. Assim, os conhecimentos sobre o tema podem ser ampliados e enriquecidos a partir da identificação das 
causas nos âmbitos estadual, nacional e internacional que envolvem o contexto da dívida de Santa Catarina e do Brasil.

R. Cont. Ufba, Salvador-Ba, v. 9, n. 3, p. 64 - 82, set-dez 2015 


\section{REFERÊNCIAS}

BACEN - Banco Central do Brasil. Índices de preços: preços ao consumidor. Padrão Especial de Disseminação de Dados (PEDD). Disponível em: <http://www.bcb.gov.br/sddsp/ indprecoscons_p.htm>. Acesso em: 18 dez. 2013.

BRASIL. Constituição (1988). Constituição da República Federativa do Brasil: promulgada em 5 de outubro de 1988. Atualizada até a Emenda Constitucional n. ${ }^{\circ}$ 77, de 11 de fevereiro de 2014. Presidência da República. Casa Civil. Subchefia para Assuntos Jurídicos. Disponível em: <http://www.planalto.gov.br/ccivil_03/constituicao/ constituicao.htm>. Acesso em: 13 abr. 2014.

Decreto n. ${ }^{\circ}$ 93.872, de 23 de dezembro de 1986. Dispõe sobre a unificação dos recursos de caixa do Tesouro Nacional, atualiza e consolida a legislação pertinente e dá outras providências. Disponível em: <http://www.planalto.gov.br/ccivil_03/decreto/d93872.htm>. Acessado em: 08 set. 2013.

. Lei Complementar n. ${ }^{\mathbf{0}}$ 101, de 4 de maio de 2000 (Lei de Responsabilidade Fiscal). Estabelece normas de finanças públicas voltadas para a responsabilidade na gestão fiscal e dá outras providências. Disponível em: <http://www.planalto.gov.br/ccivil_03/leis/lcp/lcp101. htm>. Acesso em: 19 maio 2014.

Lei n. ${ }^{\circ}$ 12.527, de 18 de novembro de 2011. Regula o acesso a informações previsto no inciso XXXIII do art. $5^{\circ}$, no inciso II do $\S 3^{\circ}$ do art. 37 e no $\S 2^{\circ}$ do art. 216 da Constituição Federal; altera a Lei n. ${ }^{\circ} 8.112$, de 11 de dezembro de 1990; revoga a Lei n. ${ }^{\circ}$ 11.111, de 5 de maio de 2005, e dispositivos da Lei n. ${ }^{\circ} 8.159$, de 8 de janeiro de 1991; e dá outras providências. Disponível em: <http://www.planalto.gov.br/ccivil_03/_ato20112014/2011/lei/112527.htm>. Acesso em: 17 maio 2014.

CFC - Conselho Federal de Contabilidade. Resolução CFC n. ${ }^{\circ}$ 1.128, de 21 de novembro de 2008. Aprova a NBC T 16.1 - Conceituação, Objeto e Campo de Aplicação. Disponível em: <http://www.cfc.org.br/sisweb/sre/detalhes_sre.aspx?Codigo=2008/001128>. Acesso em: 02 abr. 2014.

Resolução CFC n. ${ }^{\circ}$ 1.268, de 10 de dezembro de 2009. Altera, inclui e exclui itens das NBC T 16.1, 16.2 e 16.6 que tratam das Normas Brasileiras de Contabilidade Técnicas aplicadas ao Setor Público e dá outras providências. Disponível em: <http://www.cfc.org.br/ sisweb/sre/detalhes_sre.aspx?Codigo=2008/001128>. Acesso em: 02 abr. 2014.

IBGE - Instituto Brasileiro de Geografia e Estatística. Contas Regionais do Brasil de 2002. Disponível em: <http://www.ibge.gov.br/home/estatistica/economia/contasregionais/2002>. Acesso em: 10 mar. 2014. 2002.

Contas Regionais do Brasil de 2012. Disponível em: <http://www.ibge.gov.br/ home/estatistica/economia/contasregionais/2012/default_ods_2002_2012.shtm>. Acesso em: 16 nov. 2014. 2012.

Estados @: Santa Catarina. Disponível em: <http://www.ibge.gov.br/estadosat/ perfil.php?sigla=sc>. Acesso em: 10 mar. 2014. 2014.

Índice Nacional de Preços ao Consumidor Amplo - IPCA e Índice Nacional de Preços ao Consumidor - INPC. Disponível em: <http://www.ibge.gov.br/home/estatistica/ indicadores/precos/inpc_ipca/defaultinpc.shtm>. Acesso em: 18 dez. 2013.

KOHAMA, Heilio. Contabilidade Pública: teoria e pratica. 11. ed. São Paulo: Atlas, 2010. MACHADO, Joyce de Andrade; MELLO, Gilmar Ribeiro. A Lei Responsabilidade Fiscal e o impacto sobre o endividamento dos municípios paranaenses. In: $11^{\circ}$ Congresso USP de 
Controladoria e Contabilidade e $8^{\circ}$ Congresso USP de Iniciação Científica em Contabilidade, 2011, São Paulo. Anais do $11^{\circ}$ Congresso USP de Controladoria e Contabilidade e $8^{\circ}$ Congresso USP de Iniciação Científica em Contabilidade, 2011. Disponível em: <http://www. congressousp.fipecafi.org/web/artigos112011/279.pdf>. Acesso em: 18 out. 2014.

MELLO, Gilmar Ribeiro; DALCHIAVON, Eloisa Carla. A Lei de Responsabilidade Fiscal e o impacto sobre o endividamento dos Municípios Potiguares. Contextus - Revista Contemporânea de Economia e Gestão v. 2, p. 1-15, 2012. Disponível em: <http://www. contextus.ufc.br/index. php/contextus/article/view/496>. Acesso em: 18 out. 2014.

MESSIAS SILVA, Sheila; LOPES, Jorge E. G.; PEDERNEIRAS, Marcleide M. M.; PAULO, Edilson. Dez anos de responsabilidade fiscal: um estudo da evolução da dívida pública da Prefeitura do Recife. Revista Ambiente Contábil, v. 4, p. 1-17, 2012. Disponível em: <http://periodicos.ufrn.br/ambiente/article/view/2136>. Acesso em: 18 out. 2014.

PNUD - Programa das Nações Unidas para o Desenvolvimento. Atlas do desenvolvimento humano no Brasil 2013: Ranking todos os estados 2010. Disponível em:

<http://atlasbrasil.org.br/2013/pt/ranking>. Acesso em: 10 mar. 2014.

QUEIROZ, Éber Wesley Lemos de. Pacto de austeridade fiscal: um diagnóstico da dívida consolidada líquida dos municípios do Estado de Pernambuco entre os anos de 2006 a 2010. 2012. 44 f. Dissertação (Mestrado) - Curso de Mestrado Profissionalizante em Gestão Pública Para O Desenvolvimento do Nordeste, Universidade Federal de Pernambuco, Pernambuco, 2012. Disponível em: <http://bancodeteses.capes.gov.br>. Acesso em: 18 out. 2014.

RAUPP, Fabiano Maury; BEUREN, Ilse Maria. Metodologia da pesquisa aplicável às Ciências Sociais. In: BEUREN, Ilse Maria. (Org.). Como elaborar trabalhos monográficos em Contabilidade: teoria e prática. 2. ed. São Paulo: Atlas, 2004. Cap. 3. p. 76-97.

SANCHES, Osvaldo Maldonado. Novo dicionário de orçamento e áreas afins. Edição do autor, 2013.

SENADO FEDERAL. Resolução n. ${ }^{\circ}$ 40, de 20 de dezembro de 2001. Dispõe sobre os limites globais para o montante da dívida pública consolidada e da dívida pública mobiliária dos Estados, do Distrito Federal e dos Municípios, em atendimento ao disposto no art. 52, VI e IX, da Constituição Federal. Atualizada com a Resolução n. ${ }^{\circ}$ 5/2002. Disponível em: <http://legis.senado.gov.br/legislacao/ListaTextoIntegral.action?id=242464>Acesso em: 18 maio 2014.

SC - SANTA CATARINA. Conheça Santa Catarina: Santa Catarina entre os melhores Estados do país. Disponível em: <http://www.sc.gov.br/index.php/conheca-sc>. Acesso em: 15 jan. 2014. 2014a.

Demonstrativos da Dívida Consolidada Líquida: Anexos II dos Relatórios de Gestão Fiscal referentes aos $3^{\circ}$ s quadrimestres dos anos de 2000 e 2001. Secretaria de Estado da Fazenda. [mensagem pessoal]. Assunto: <Relatório de Gestão Fiscal>. Arquivos em anexos: <AnexoXIIIDivConseMobiliária 2000.xls> e <AnexoXIIIDividaCons Mobiliaria.xls>. Data de recebimento: 16 set. 2012. 2000 e 2001.

Demonstrativos da Dívida Consolidada Líquida: Anexos II dos Relatórios de Gestão Fiscal referentes aos $3^{\circ}$ s quadrimestres dos anos de 2002 a 2013. Secretaria de Estado da Fazenda. Disponível em: <http://www.sef.sc.gov.br/transparencia/gest\%C3\%A3ofiscal/relatorios/491>. Acesso em: 10 fev. 2014. 2002 a 2013.

Economia: economia de Santa Catarina é rica e diversificada. Disponível em: <http://www.sc.gov.br/index.php/economia>. Acesso em: 15 jan. 2014. 2014 b. 
História: confira algumas curiosidades sobre nosso estado. Disponível em: <http://www.sc.gov.br/index.php/historia>. Acesso em: 10 mar. 2014. 2014c.

SILVA, Anderson Caputo; CARVALHO, Lena Oliveira de; MEDEIROS, Otavio Ladeira de (Org.). Dívida pública: a experiência brasileira. Brasília: Secretaria do Tesouro Nacional e Banco Mundial, 2009. Disponível em: <http://www.tesouro.fazenda.gov.br/o-que-e-a-dividapublica-federal->. Acesso em 16 nov. 2014.

SILVA, Lino Martins da. Contabilidade Governamental: um enfoque administrativo. 9. ed. São Paulo: Atlas, 2011.

SRFB - Secretaria da Receita Federal do Brasil. Resultado da Arrecadação - Anos Anteriores. Disponível em: <http://www.receita.fazenda.gov.br/Historico/Arrecadacao/ ResultadoArrec/default.htm>. Acesso em: 05 mar. 2015.

STN - Secretaria do Tesouro Nacional. Indicadores fiscais e de endividamento de estados e municípios. Sistema de Coleta de Dados Contábeis dos Entes da Federação (SISTN).

Disponível em: <https://www.tesouro.fazenda.gov.br/-/indicadores-fiscais-e-deendividamento-de-estados-e-municipios?redirect=https $\% 3 \mathrm{~A} \% 2 \mathrm{~F} \% 2 \mathrm{Fwww}$.tesouro.fazenda. gov.br\%2Fhome\%3Fp_p_id\%3D101_INSTANCE_5wsRhVpMwY13\%26p_p_lifecycle\%3D 0\%26p_p_state\%3Dnormal\%26p_p_mode\%3Dview\%26p_p_col_id\%3D_118_INSTANCE_ RKHzMXDjhA7G_column-1\%26p_p_col_count\%3D1>. Acesso em: 20 set. 2014. 2014a.

Portaria n. ${ }^{\circ}$ 553, de 22 de setembro de 2014. Aprova a $6^{a}$ edição do Manual de Demonstrativos Fiscais (MDF). Disponível em: 〈http://www.tesouro.fazenda.gov.br/-/mdf > . Acesso em: 5 out. 2014. 2014b. 